\title{
The Similarity and Frequency of Proposals to Reform US Medical Education
}

\section{Citation}

Christakis, Nicholas A. 1995. "The Similarity and Frequency of Proposals to Reform US Medical Education." JAMA 274 (9) (September 6): 706. doi:10.1001/jama.1995.03530090038019.

\section{Published Version}

doi:10.1001/jama.1995.03530090038019

\section{Permanent link}

http://nrs.harvard.edu/urn-3:HUL.InstRepos:33839960

\section{Terms of Use}

This article was downloaded from Harvard University's DASH repository, and is made available under the terms and conditions applicable to Other Posted Material, as set forth at http:// nrs.harvard.edu/urn-3:HUL.InstRepos:dash.current.terms-of-use\#LAA

\section{Share Your Story}

The Harvard community has made this article openly available.

Please share how this access benefits you. Submit a story.

\section{Accessibility}




\title{
The Similarity and Frequency of Proposals to Reform US Medical Education
}

\section{Constant Concerns}

\author{
Nicholas A. Christakis, MD, PhD, MPH
}

Objectives.-To identify the values and agendas underlying reports advocating the reform of medical education and to account for their similarity and repeated promulgation.

Data Sources.-Major reports regarding undergraduate medical education reform published between 1910 and 1993 were identified through a manual bibliographic search.

Study Selection.-Nineteen of a total of 24 reports met the two inclusion criteria: they directly addressed undergraduate medical education and contained a coherent body of recommendations.

Data Extraction.-Content analysis of 19 reports.

Data Synthesis.-All the reports articulate a specifically social vision of the medical profession, in which medical schools are seen as serving society. The reports are remarkably consistent regarding the objectives of reform and the specific reforms proposed. Core objectives of reform include the following: (1) to better serve the public interest, (2) to address physician workforce needs, (3) to cope with burgeoning medical knowledge, and (4) to increase the emphasis on generalism. Proposed reforms have tended to suggest changes in manner of teaching, content of teaching, faculty development, and organizational factors. Reforms such as increasing generalist training, increasing ambulatory care exposure, providing social science courses, teaching lifelong and self-learning skills, rewarding teaching, clarifying the school mission, and centralizing curriculum control have appeared almost continuously since 1910 .

Conclusion.-The similarity of the reports' objectives and reforms results not only from a similar body of problems, but also from the reaffirmation of similar values. The reports have two implicit agendas that transcend the reform of medical education: the affirmation of the social nature of the medical profession and selfregulation of the profession. These agendas help account for the reports' similarity and their repeated promulgation.

(JAMA. 1995;274:706-711)

IN 1910, Abraham Flexner released his famous report recommending the radical reform of medical education in the United States. While this report was successful in its main intentions, ${ }^{1}$ in retrospect it can be seen as only the initial salvo in what has been nearly a century of successive reform proposals. ${ }^{24}$ Indeed, in the intervening years, there have been at least 24 major reports advocating reform, and such reports are currently emerging virtually annually. Typically, these reports identify strikingly similar

From the Departments of Medicine and Sociology, University of Chicago (III).

Corresponding author: Nicholas A. Christakis, MD, $\mathrm{PhD}, \mathrm{MPH}$, The University of Chicago Medical Center, 5841 S Maryland Ave, MC 6098, Chicago, IL 60637. problems with medical education, claim that previous reports have gone relatively unheeded, argue that reform is essential and urgent, and prescribe corrections that are also strikingly similar.

The existence of so many similar reports in such a relatively short period raises a perplexing question regarding medical education: either medical schools have remained intractably devoted to deficient modes of education-which seems unlikely, especially given the real changes that have occurred in medical educationor there is another rationale for the promulgation of these reports. In this article, I argue there is an ethos of reform in US medical education that has two purposes that transcend improving the educational experience of medical students: the reaf- firmation of certain core values of the profession and the self-regulation of the profession. In developing this argument, I review the reports' objectives and recommendations, elucidate their underlying rhetorical structure, and describe their implicit and explicit functions in sustaining the medical profession. Since this analysis is limited to the reports and does not include actual educational practice, it is not possible to assess the extent to which medical education has evolved as a result of, or despite, the reform proposals.

\section{METHODS}

This article focuses on 19 of 24 major reports on the status and promise of medical education published between 1910 and 1993 (Table 1). The 19 reports directly address undergraduate medical education and contain a coherent body of recommendations.-23 Reports not meeting these criteria are not included in this analysis. $24-28$ Detailed content analysis was used to identify and explicate themes in the reports. I provide illustrative rather than comprehensive quotations to illustrate the themes; greater detail is available elsewhere..$^{29}$

\section{RESULTS}

\section{The Affirmation of Core Values}

The purpose of medicine and medical schools articulated by the reports has remained relatively constant since 1910 . In general, the reports suggest that medicine as a discipline and physicians as professionals exist to serve society. Flexner, for example, argues, "The medical profession is a social organ, created not for the purpose of gratifying the inclinations or preferences of certain individuals, but as a means of promoting health, physical vigor, happiness-and the economic independence and efficiency immediately connected with these factors." ${ }^{(\mathrm{p} 42)}$

This dependence of medicine on society is not without consequences; it generates a reciprocal obligation of medical schools and the medical profession to 
Table 1.-Major Reports on the Reform of Undergraduate Medical Education*

\begin{tabular}{|c|c|c|}
\hline Year & Title & Sponsor \\
\hline 1910 & Medical Education in the United States and Canada & Carnegie \\
\hline 1932 & Final Report of the Commission on Medical Education & AAMC \\
\hline 1940 & Medical Education in the United States, 1934-1939 & AMA \\
\hline 1953 & Medical Schools in the United States at Mid-Century & AMA, AAMC \\
\hline 1959 & Physicians for a Growing America & PHS \\
\hline 1965 & Planning for Medical Progress Through Education & AAMC \\
\hline $1966 \mathrm{a}$ & Medical Education Reconsidered & ASA \\
\hline $1966 b$ & The Graduate Education of Physicians & AMA \\
\hline 1970 & $\begin{array}{l}\text { Higher Education and the Nation's Health: Policies for Medical } \\
\text { and Dental Education }\end{array}$ & Carnegie \\
\hline 1972 & A Handbook for Change & SAMA \\
\hline 1982 & Future Directions for Medical Education & AMA \\
\hline 1983 & $\begin{array}{l}\text { The New Biology and Medical Education: Merging the Biological, } \\
\text { Information, and Cognitive Sciences }\end{array}$ & Macy \\
\hline 1984 & Physicians for the Twenty-First Century & AAMC \\
\hline 1989 & Clinical Education and the Doctor of Tomorrow & NYAS \\
\hline 1991 & $\begin{array}{l}\text { Healthy America: Practitioners for 2005: An Agenda for Action } \\
\text { for US Health Professions Schools }\end{array}$ & Pew \\
\hline $1992 a$ & Improving Access to Health Care Through Physician Workforce Reform & PHS \\
\hline $1992 b$ & Medical Education in Transition & RWJ \\
\hline $1992 \mathrm{c}$ & $\begin{array}{l}\text { Educating Medical Students: Assessing Change in Medical Education, } \\
\text { The Road to Implementation }\end{array}$ & AAMC \\
\hline$\overline{1993}$ & $\begin{array}{l}\text { Health Professions Education for the Future: Schools } \\
\text { in the Service of the Nation }\end{array}$ & Pew \\
\hline
\end{tabular}

*Reports have been selected for analysis only if they contain a coherent body of recommendations on improving education at medical schools. Carnegie indicates Carnegie Foundation; AAMC, Association of American Medical Colleges; AMA, American Medical Association; PHS, Public Health Service; ASA, American Surgical Association; SAMA, Student American Medical Association; Macy, Josiah Macy Foundation; NYAS, New York Academy of Sciences; Pew, Pew Health Professions Commission; RWJ, Robert Wood Johnson Foundation.

accommodate societal needs. Elsewhere, Flexner notes,

The physician is a social instrument. If there were no disease, there would be no doctors. And as disease has consequences that immediately go beyond the individual specifically affected, society is bound to protect itself against unnecessary spread of loss or danger.... Practically the medical school is a public service corporation. It is chartered by the state; it utilizes public hospitals on the ground of the social nature of its service. The medical school cannot then escape social criticism and regulation. ${ }^{5(p 154)}$

Similar themes are developed in all the reports. For example, the 1966 American Medical Association (AMA) report observes, "Medicine exists to serve society.... [It] must ever be responsive to the needs of the society it serves."12(p19) The 1989 New York Academy of Sciences report notes that "faculties and schools of medicine are failing in too many instances to produce socially responsible doctors who unequivocally recognize medicine as a social good, not a commercial commodity." 18 (p110) And the 1991 report by the Pew Health Professions Commission also portrays "the education and training of health professionals" as being subservient to the "health needs of the American people."1(piii) "Failure to make an effort to understand and respond [to community needs]," it argues, "violates the basic covenant between health professionals and people they have obligated themselves to serve." ${ }^{.194)}$ The reports charac- other alternatives, for, if the profession does not take responsibility, society will surely demand that the vacuum be filled and the government assume the responsibility. ${ }^{12(p v i)}$

By the mid 1960s, the relationship between the public on the one hand and the schools and the profession on the other undergoes a subtle but important transformation: from voluntary supply of an essential societal need to involuntary response to an exacting societal demand. For example, the 1966 American Surgical Association (ASA) report observes, "The number of those who make demands upon the medical profession has steadily increased. But superimposed upon this increase in numbers has been an even more significant increase in expectations. ..."11(18) Meeting the needs of the public comes to be configured as a potentially unreasonable public expectation rather than as the appropriate fulfillment of a public trust:

There are pressures for success on the medical community that have never before existed-pressures, moreover, that the community itself would dearly like to satisfy, however unreasonable they may appear.... In the end, this is focused on the school of medicine. It must provide, somehow, generalists with a wide range of knowledge and skills; specialists with a profundity of insight and the capacity to manage increasingly intricate facilities; research men who can move medicine steadily forward toward new goals; medical men akin in function and in spirit to systems engineers-all of these in numbers greater than ever before: and it must do all this in the face of insatiable public demand for accomplishment. ${ }^{11(\mathrm{p} 23-24)}$

The 1965 Association of American Medical Colleges (AAMC) report notes, "Not only have expectations risen but, more importantly, an attitude of 'entitlement' is becoming increasingly prevalent." $10(\mathrm{p} 17)$ And the 1982 AMA report states, "The public has ... expected more immediate results from the money provided for research. Expectations have not been realistic. ..."15(p9)

The quasi-adversarial relationship suggested in these reports, by discussion of "demands," "expectations," "entitlements," and "rights" that are "unrealistic" or "insatiable" is altogether different from the way such things were discussed in earlier reports. Before the 1960 s, reports conceptualize public exigencies as "desires," "wishes," or simply "needs."

\section{The Objectives of Reform}

Eight basic objectives of reform emerge in the proposals to reform medical education (Table 2), and these may be grouped in two categories: core objectives and secondary objectives. The core objectives reflect the social obligation of medical schools discussed herein, 
occur frequently within each report and across reports, and address fundamental purposes underlying medical education. The secondary objectives are less tightly linked to the social nature of medicine, occur less frequently, and are less fundamental.

In order of their overall centrality to reform proposals (in terms of the quantity and quality of the attention they are accorded within and across the reports), the four core objectives are (1) to better serve the public interest, (2) to address physician workforce needs, (3) to cope with burgeoning medical knowledge, and (4) to increase the generalist character of medical education.

The first core objective, to better meet the needs of the community, is not restricted to the number and type of physicians produced by medical schools; it also refers to the types of diseases investigated by medical schools and to the way those schools deliver health care. For instance, the 1932 AAMC report emphasizes the fact that reforms are needed to bring medical education into "a more satisfactory relationship" with the "needs of society." $\%(p 1)$ In the most explicit exposition of this objective, linking the proposed reform of medical education and the nature of the medical profession, the 1993 Pew report observes,

The health professions are respected because of the special, almost sacred, role they have in matters of life and death. This most human of all enterprises-welcoming new life, aiding the sick, and comforting the dying - should be one that is always held in the highest esteem by those who benefit from these services. The only legitimate source for such a position in society is when it is drawn from the health care needs of the public. If the professions are to be reserved from becoming just associations for health care workers, then their work must begin and end on the fundamental values that define and shape their calling. ${ }^{23(p 13)}$
The second core objective of reform is to address the workforce needs of society, in terms of numbers of physicians and their distribution. This objective, like the foregoing one, grows out of the social covenant of medical schools. For example, the need to increase the number of physicians was a powerful objective of medical education reform from the mid 1960s to the late 1970s, and the 1965 AAMC report noted,

Few persons ... believe [the medical education] improvements needed are matters of minor adjustment. Most point to the need to take major steps to improve medical education - to enable the nation to produce more and better prepared physicians and other health personnel. ${ }^{10(\text { pviii) }}$

There is an almost deliberate conflation of the "improvement" of medical education on the one hand and increasing the number of physicians on the other.

The third core objective is to cope with the burgeoning knowledge base of medicine. For example, the 1965 AAMC report begins with the observation, "During the past half century, advances in medicine have been more significant and rapid than in any previous periods of human history." (o(p1) It elaborates further,

The phenomenal growth of knowledge during this period has increased at an ever-accelerating pace. Although still attempted, it is becoming more apparent to the educator that it is no longer possible to provide encyclopedic coverage of the contents and skills of medicine within the limited time available. ${ }^{10(p 9)}$

The 1992 Robert Wood Johnson Foundation report similarly observes, "Biomedical research has created an explosion in the volume, complexity, and rate of change of medical information. When the sum of it all seems to strain human cognitive capacities, the effective management of information becomes critical."21(p3) Reform is needed, the reports argue, to enhance the way the educational system handles this constant "explosion" of knowledge.

The fourth core objective of reform, to maintain a "broad" and "generalist" character to medical education, finds two expressions: to reform education so that it is less "fragmented" and to reform education so as to increase student interest in generalist careers. In the context of discussing the goals of reform, the 1966 AMA report notes, "Specialization, with all of its advantages, has led to a fragmentation, an insufficiency of physicians who are competent and willing to offer comprehension and continuing care."12(p30) The 1989 New York Academy of Sciences report notes, "Clinical education has drifted away from being a broad preparation of the undifferentiated doctor and is becoming an increasingly fragmented, technicallyoriented training program for specialists."12(p110) With respect to the objective of increasing the emphasis on generalism, the reports are virtually unanimous. Arguing that specialization was corrupting undergraduate medical education, the 1932 AAMC report observes,

There has been a tendency in recent years to attempt to provide instruction in the medical course in the various special fields of practice. This has been responsible in part for the great overburdening of the curriculum and the confusion regarding the purposes of the basic training. Changes in the methods and forms of practice should not be the guide for determining the educational needs of the medical students. ${ }^{6(p 172)}$

The 1982 AMA report summarizes this objective of reform as follows:

The major theme of this report is the balance between generalism and specialism required to permit individuals to develop into welleducated physicians who possess a broad perspective of society.... The basic premise underlying many of the recommendations in

Table 2.-Explicit Objectives of Proposals to Reform Medical Education*

Report Year

Objectives

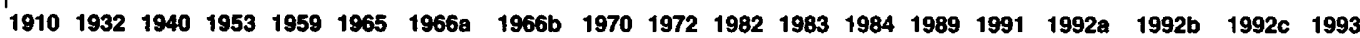

\begin{tabular}{|c|c|c|c|c|c|c|c|c|c|c|c|c|c|c|c|c|c|c|c|}
\hline $\begin{array}{l}\text { Core } \\
\text { Serve changing public interest }\end{array}$ & $x$ & $x$ & & $x$ & & $x$ & & $x$ & $x$ & & $x$ & & $x$ & $x$ & $x$ & $x$ & & & $x$ \\
\hline $\begin{array}{l}\text { Address physician workforce } \\
\text { needs }\end{array}$ & $x$ & $x$ & & & $x$ & $x$ & $x$ & & $x$ & $x$ & & & & & & $x$ & & & \\
\hline Cope with burgeoning knowledge & $x$ & $\mathrm{x}$ & $x$ & & $x$ & $x$ & $x$ & $x$ & $x$ & $x$ & $x$ & $x$ & $x$ & & & & $x$ & $x$ & $x$ \\
\hline $\begin{array}{l}\text { Foster generalism; decrease } \\
\text { fragmentation }\end{array}$ & & $\mathrm{x}$ & & $x$ & & & & $x$ & & $x$ & $x$ & & $x$ & $x$ & $x$ & $x$ & $x$ & & $x$ \\
\hline $\begin{array}{l}\text { Secondary } \\
\text { Apply new educational methods }\end{array}$ & & $x$ & & $x$ & & $x$ & $x$ & & & $x$ & & $x$ & $x$ & $x$ & & & & & \\
\hline $\begin{array}{l}\text { Address changing nature } \\
\text { of illness burden }\end{array}$ & & & & & & $x$ & & & $x$ & & & & $x$ & & $x$ & & $x$ & & \\
\hline $\begin{array}{l}\text { Address changing nature } \\
\text { of practice }\end{array}$ & & & & & $x$ & $x$ & & $x$ & $x$ & $x$ & & & $x$ & & & & & & \\
\hline $\begin{array}{l}\text { Increase quality and standards } \\
\text { of education }\end{array}$ & $x$ & $x$ & $x$ & $x$ & $x$ & $x$ & & & $x$ & $x$ & & $x$ & $x$ & & & & & $x$ & \\
\hline
\end{tabular}

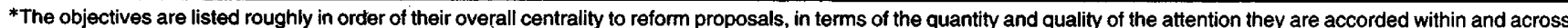

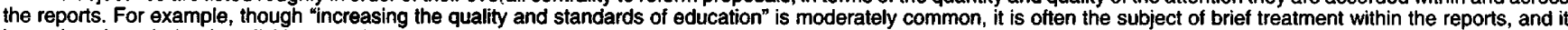
is rarely acknowledged explicitly as an important objective. See Table 1 for titles of reports corresponding to years indicated. 
this report is that physicians should be broadly educated if medicine is to continue to be a highly respected profession. ${ }^{15(\mathrm{pi})}$

Fostering generalism is implicitly linked with the special relationship between the medical profession and society.

The four secondary objectives of medical education reform, in order of centrality, are (1) to apply new methods of teaching, (2) to address the changing illness burden confronted by society, (3) to address the changing nature of practice arrangements, and (4) to increase the quality of education.

Part of the impetus to reform has been the desire to apply ostensibly new pedagogic methods. For example, the first sentence of the 1932 AAMC report states as its purpose "to make suggestions which would bring [medical education] into more satisfactory relationships with the newer conceptions and methods of university education." ${ }^{6(p 1)}$ The 1966 ASA report similarly notes that "the change in the understanding of educational process [is] one of the bases of the need for change." $11(\mathrm{p} 30)$

Efforts to reform medical education have also had the twin objectives of bringing medical education into alignment with the changing nature of medical practice and the changing illness burden in society. For example, the 1984 AAMC report notes that "medical faculties should adapt the general professional education of students to changing demographics and the modifications occurring in the health care system," that "chronic disease is growing dramatically," that "acute care hospital utilization is decreasing," and that "new organizational forms [for delivering health care] have appeared...."17(p6)

Increasing the quality of medical education, while a fairly common objective of reform, is rarely explicitly treated as important or central in the reports. When this objective does appear, especially in the early reports, it is usually out of concern that too many practitioners of "indifferent" quality were being let loose on an "innocent public."

\section{The Proposed Reforms}

The reports have been extraordinarily consistent in the specific reforms proposed to achieve the eight objectives delineated herein and to correct the perceived deficiencies in medical education-to the point that the wording of some of the recommendations is identical. Reforms may be grouped in four categories: manner of teaching, content of teaching, faculty development, and organizational factors. As shown in Table 3, few reforms emerge as truly novel. Many currently popular reforms have been advocated since the earliest reports and have appeared almost continuously since then.

In some cases, there is a relatively straightforward link between the objective of reform and the specific reform proposed in the report. For example, the burgeoning of medical knowledge drives changes in the content of education and also drives the necessity to teach students habits of "lifelong learning." Addressing societal workforce needs is directly linked to a number of specific reforms, such as increasing class size, decreasing the length of training, and moving curricular elements from medical school back to undergraduate schools. And the changing nature of disease patterns and practice arrangements is often used to motivate proposals to increase the social sciences. In other cases, however, the link between the objectives and the reforms is less explicit; for example, the proposal to reform evaluation methods is only implicitly linked with the objective of increasing the quality of medical school education.

Teaching students to be lifelong learners has been the most consistent reform proposed by the reports, appearing in virtually all of them. While the term "lifelong learning" first appeared in the 1983 Josiah Macy Foundation report, ${ }^{16(p 67)}$ the notion was present from the beginning of efforts to reform medical education; for example, the 1932 AAMC report notes, "[Medical school] can only begin the education of the physician, for he must remain a student throughout life."6(p171) Similarly, the reports endorse "problemsolving methods of teaching that require students to seek out, rather than be given, information"17(p12) and "educational experiences that require students to be active, independent learners and problemsolvers rather than passive recipients of information." $20(\mathrm{p} 30)$

The most common proposals regarding the content taught at medical schools are to increase generalism and ambulatory care exposure, and many reports recommend outpatient over inpatient settings for education. The proposal to increase the amount of social science training in the curriculum is a prominent manifestation of the reports' articulated commitment to the notion of medicine as a social good, although what is considered to be a "social science" has varied considerably over the years.

Proposals to reward teaching have been around since the earliest reports as well. The 1932 AAMC report observes,

If clinical teaching is to attract and hold teachers of the caliber and ability which it requires, and provide a corps of younger instructors from which the senior members of the staff may be recruited, there must be a fuller recognition of the freedom and dignity which such work should command.... It is vital that universities provide the inducements which will attract and hold clinicians of the caliber and ability which teaching in this field requires and which the responsibilities for the care of patients in the hospitals and clinies demand. ${ }^{6(p 245,248)}$

The 1970 Carnegie Commission report recommends that universities "place greateremphasis on teaching as arewarding scholarly activity for the faculty, especially in connection with salary and promotion policies." ${ }^{3(p 92)}$ Similar invocations appear in virtually every subsequent report.

\section{CONCLUSION}

Proposals to reform medical education have three rhetorical parts: they articulate (1) a purpose of medicine and medical schools, (2) objectives of reform, and (3) specific reforms. These three parts are systematically related: the reforms are in keeping with the objectives, which are in keeping with the perceived purpose. In addition to sharing this rhetorical structure, the reports have also articulated a remarkably similar purpose of medicine, identified remarkably similar objectives of reform, and proposed remarkably similar reforms. For nearly a century, in spite of dramatic changes in the context in which medicine is practiced (in terms of the illness burden in the United States, the diagnostic and therapeutic armamentarium, and the organization of medical care), the reports suggesting reform of US medical education have been strikingly similar in structure, content, and tone.

What accounts for this similarity? There are at least three possible explanations. One is that the problems with medical education are inherently irremediable. Another is that efforts to achieve reform, and the commitment to do so, have been inadequate. But, as indicated herein, a more likely explanation is that important purposes in addition to reform may underlie and motivate the promulgation of these reports.

With respect to the first explanation, it does not seem credible that problems in medical education are insoluble or that medical education cannot be changed. Indeed, several reports acknowledge that significant change in medical education has occurred. ${ }^{8,10,21}$ Nevertheless, it is also true that there are certain structural problems inherent in medical education that are themselves invariant. For example, each report has had to contend with the problem that there has always been and will always be too much to know; medical knowledge is theoretically and practically limitless. Moreover, the solution to this problem is to sug- 


\begin{tabular}{|c|c|c|c|c|c|c|c|c|c|c|c|c|c|c|c|c|c|c|c|}
\hline \multirow[b]{2}{*}{ Proposed Reform } & \multicolumn{19}{|c|}{ Report Year } \\
\hline & 1910 & 1932 & 1940 & 1953 & 1959 & 1965 & $1966 \mathbf{a}$ & $1966 \mathrm{~b}$ & 1970 & 1972 & 1982 & 1983 & 1984 & 1989 & 1991 & $1992 a$ & 1992b & $1992 \mathrm{c}$ & 1993 \\
\hline $\begin{array}{l}\text { Manner of teaching } \\
\text { Teach lifelong learning }\end{array}$ & $x$ & $x$ & $x$ & $\mathrm{x}$ & & $\mathrm{x}$ & & $x$ & $x$ & $x$ & $x$ & $\mathrm{x}$ & $\mathrm{x}$ & $\mathbf{x}$ & $x$ & & $x$ & $\mathrm{x}$ & $\mathrm{x}$ \\
\hline Teach self-learning & & $x$ & $\mathrm{x}$ & $\bar{x}$ & $x$ & & & & & $x$ & & $x$ & $\mathrm{x}$ & & $\bar{x}$ & & $\bar{x}$ & $\bar{x}$ & $x$ \\
\hline $\begin{array}{l}\text { Use case method or } \\
\text { problem-based learning }\end{array}$ & $x$ & & & & & $x$ & & & & $x$ & & $x$ & $x$ & & & $x$ & $x$ & $x$ & $x$ \\
\hline Decrease lectures & $\bar{x}$ & $x$ & $x$ & & & $x$ & & & & $\bar{x}$ & & $\bar{x}$ & $\bar{x}$ & & & & & $\bar{x}$ & \\
\hline $\begin{array}{l}\text { Increase interdisciplinary } \\
\text { teaching }\end{array}$ & & $x$ & $\mathrm{x}$ & $x$ & & & & & & $\mathrm{x}$ & & & $\mathrm{x}$ & $x$ & & & $x$ & $\mathrm{x}$ & \\
\hline Increase mentorship & $x$ & $x$ & $\mathrm{x}$ & $\bar{x}$ & & & & & & & & $x$ & $\bar{x}$ & & & $x$ & & & \\
\hline Reform evaluation methods & & & & $x$ & & & & & & $x$ & $\mathrm{x}$ & $\mathrm{x}$ & $\mathrm{x}$ & $\mathrm{x}$ & & & $x$ & $\mathrm{x}$ & \\
\hline Use standardized patients & & & & & & & & & & & & & & & & & $\bar{x}$ & $x$ & \\
\hline Increase unscheduled time & & & & $x$ & & & & & & & & $x$ & $x$ & & & & & & \\
\hline Encourage public service & & & & & & & & & $x$ & $\bar{x}$ & & & & $\bar{x}$ & & & & & \\
\hline $\begin{array}{l}\text { Content of teaching } \\
\text { Increase generalism }\end{array}$ & & $x$ & & $x$ & & & & $x$ & & $x$ & $x$ & & $x$ & $x$ & $x$ & $x$ & & & $x$ \\
\hline Increase ambulatory care & $\bar{x}$ & $\bar{x}$ & & & & & & $\bar{x}$ & $\bar{x}$ & $\bar{x}$ & $\bar{x}$ & & $\bar{x}$ & $\mathrm{x}$ & $\bar{x}$ & $\mathrm{x}$ & $x$ & & $x$ \\
\hline Foster humanism & $\bar{x}$ & $\bar{x}$ & & & & & & & & & $\bar{x}$ & & & & & $\mathrm{x}$ & & & $\bar{x}$ \\
\hline Increase social sciencet & & $\mathbf{x}$ & & & & $x$ & $x$ & & $\mathbf{x}$ & $\mathbf{x}$ & & $\mathbf{x}$ & $\mathrm{x}$ & & & & $\mathbf{x}$ & & $\mathrm{x}$ \\
\hline Stress prevention & $\bar{x}$ & $\bar{x}$ & $x$ & & & & & $x$ & & $\bar{x}$ & & & $\bar{x}$ & & $\bar{x}$ & & & & $\mathrm{x}$ \\
\hline Stress community heatth & & $x$ & & & & & & & & $x$ & & & $x$ & & $x$ & $x$ & & & $\bar{x}$ \\
\hline $\begin{array}{l}\text { Teach information- } \\
\text { handling techniques }\end{array}$ & $\mathrm{x}$ & $\mathrm{x}$ & & $x$ & & & & & & $x$ & & $x$ & $\mathrm{x}$ & & $x$ & & $\mathbf{x}$ & $\mathrm{x}$ & \\
\hline Foster team skills & & $\bar{x}$ & & & & $\bar{x}$ & & $\bar{x}$ & $x$ & $\bar{x}$ & $\bar{x}$ & & & & $x$ & $x$ & & & $x$ \\
\hline $\begin{array}{l}\text { Faculty development } \\
\text { Reward teaching }\end{array}$ & $x$ & $x$ & $x$ & $x$ & & $x$ & & & $x$ & $x$ & & $x$ & $x$ & $x$ & $x$ & & $x$ & $x$ & $x$ \\
\hline Improve teaching & $\mathbf{x}$ & & & $\bar{x}$ & $\mathbf{x}$ & $\mathrm{x}$ & & & & $\bar{x}$ & & & $\bar{x}$ & & & $\mathrm{x}$ & $\bar{x}$ & $x$ & $\bar{x}$ \\
\hline $\begin{array}{l}\text { Organizational factors } \\
\text { State mission and values }\end{array}$ & & $x$ & $x$ & & & & & $x$ & & & $x$ & & & $x$ & $x$ & $x$ & & $x$ & $x$ \\
\hline $\begin{array}{l}\text { Centralize control } \\
\text { of curriculum }\end{array}$ & & & $x$ & $x$ & & & & $x$ & & $x$ & & & $x$ & $x$ & & & $x$ & $\mathrm{x}$ & \\
\hline Centralize control of budget & & & & $x$ & $x$ & & & & & & $x$ & & $x$ & $x$ & & & & $\mathrm{x}$ & \\
\hline $\begin{array}{l}\text { Integrate clinical and } \\
\text { basic sciences }\end{array}$ & & & $x$ & $x$ & & & & & $x$ & & & & $x$ & & & & $x$ & & \\
\hline $\begin{array}{l}\text { Split clinical and basic } \\
\text { sciences }\end{array}$ & & & & & & & $x$ & & & & & & & & & & & & \\
\hline $\begin{array}{l}\text { Modify admission } \\
\text { requirements }\end{array}$ & & $\mathrm{x}$ & & $\mathrm{x}$ & $\mathbf{x}$ & $x$ & $x$ & & $\mathrm{x}$ & $x$ & $\mathrm{x}$ & & $\mathrm{x}$ & $\mathbf{x}$ & & $x$ & & & \\
\hline Shorten medical school & & & & & & & $\mathrm{x}$ & & $\mathrm{x}$ & $x$ & & & & & & & & & \\
\hline Lengthen medical school & $x$ & & & & & & & & & & & & & & & & & & \\
\hline Increase university control & $x$ & $x$ & & $x$ & $x$ & $x$ & & & & & & $x$ & & & & & & & \\
\hline $\begin{array}{l}\text { Decrease the number } \\
\text { of physicians or schools }\end{array}$ & $x$ & $x$ & v & & & & & & & & & & $\cdot$ & & & & & & \\
\hline $\begin{array}{l}\text { Increase the number } \\
\text { of physicians or schools }\end{array}$ & & & & $x$ & $x$ & $x$ & $x$ & & $x$ & & & & & & & & & & \\
\hline $\begin{array}{l}\text { Bring residency under } \\
\text { medical school control }\end{array}$ & $x$ & & & $x$ & & $x$ & $x$ & $x$ & & & & & & $\mathrm{x}$ & & & & & \\
\hline
\end{tabular}

*Not all reforms ever proposed in all reports are listed. Some of the proposed reforms included in the table were implicit and some explicit in the reports. See Table 1 for titles of reports corresponding to years indicated.

t"Social science" is variously configured by the reports to include economics, ethics, behavioral science, and history, in addition to sociology and the like.

gest ways that the knowledge might be assimilated during a longer period (thus, the concept of lifelong learning or the lengthening of postgraduate medical training) or more efficiently (thus, problem-based learning and other pedagogic innovations). A further, relatively constant structural problem is that of how many and what type of physicians to produce. Optimizing the fit between workforce production and societal needs is a never-ending task, since societal needs necessarily change. Each report has thus had to deal with this problem and has tended to propose relatively straightforward corrective modifications in medical education.

The second explanation also seems unlikely to fully account for the similarity of the reports. Medical educators express substantial support for the specific reforms reviewed herein; indeed, the educators are typically the proponents of reform. For example, the great majority of educators in one recent survey strongly supported reforms such as "develop a system for evaluating and rewarding faculty for teaching excellence," "increase the integration between basic sciences and the clinical phases of medical student education," "develop testing mechanisms to evaluate students' independent problem-solving skills," and "move more clinical education from inpatient to ambulatory and community settings."30

This brings us to the third explanation. Sociologist Samuel Bloom has argued that the history of "reform without change" in medical education is accounted for by the fact that "medical education's manifest humanistic mission is little more than a screen for the research mission, which is the major concern of the institution's social structure. "3(p294) In my view, 
this is too cynical a perspective. Rather, both the similarity of the reports and their repeated promulgation may be seen to arise from the fact that the reports have two important functions other than their explicit one of reforming medical education: the affirmation of certain core professional values and the self-regulation of the profession.

The reports are all based on a consistently social vision of medicine and the medical profession, a vision that reflects an important professional value and provides the basis from which all subsequent objectives and reform proposals arise. To the extent the reports are all built on identical foundations, they are similar. Moreover, reaffirmation of this vision serves to legitimate medical education. When the gap between what medical schools are supposed to provide their communities and what they actually provide is seen as having widened inordinately, an impetus to change emerges from within the profession. By espousing the realignment of societal needs with medical school objectives, the reports preserve the role of medicine within society. And since the health care needs of a society change with the passage of time, the impetus to promulgate reform proposals is ever present.

To a large extent, the four core objectives of the reform of medical education are about the nature of the pro-

\section{References}

1. Ludmerer KM. Learning to Heal: The Development of American Medical Education. New York, NY: Basic Books; 1985.

2. Fox RC. Training in caring competence: the perennial problem in North American medical education. In: Hendrie HC, Lloyd C, eds. Educating Competent and Humane Physicians. Bloomington: Indiana University Press; 1990:119-216.

3. Bloom SW. Structure and ideology in medical education: an analysis of resistance to change. $J$ Health Soc Behav. 1988;29:294-306.

4. Enarson C, Burg FD. An overview of reform initiatives in medical education, 1906 through 1992. JAMA. 1992;268:1141-1143.

5. Flexner A. Medical Education in the United States and Canada. Boston, Mass: The Merrymount Press; 1910.

6. Rappleye WC. Medical Education: Final Report of the Commission on Medical Education. New York, NY: Association of American Medical Colleges; 1932.

7. Weiskotten HU, Schwitalia AM, Cutter WD, Anderson HH. Medical Education in the United States, 1984-1939. Chicago, Ill: American Medical Association; 1940.

8. Deitrick JE, Berson RC. Medical Schools in the United States at Mid-Century. New York, NY: MeGraw-Hill; 1953.

9. Bane F. Physicians for a Growing America. Washington, DC: US Government Printing Office; 1959.

10. Coggeshall LT. Planning for Medical Progress Through Education. Washington, DC: Association of American Medical Colleges; 1965.

11. Cope 0, Zacharias J. Medical Education Re- fession, about its values, missions, and role. The objectives address key criteria for being considered a profession. ${ }^{31}$ Specifically, better serving the public permits claims to being a profession; addressing workforce needs serves to keep control of entry in the profession within the profession; coping with the increasing amount of medical information helps identify the boundaries of professional knowledge; and preserving the generalist character of medical education provides a core set of functions for every medical professional, thereby defining the essential body of knowledge required to be identified as in the profession. By reaffirming the social values that underlie the profession and by engaging the nature and extent of its knowledge base, the reports support the moral and cognitive claims to professional expertise and autonomy.

These two tacit functions of the reports do not so much constitute discrepancies between their actual and stated purposes as they constitute additional purposes of the reports. The urge to reform is perennial; for example, new reports sponsored by the AMA, the Allegheny Health, Research, and Education Foundation, and others are on the horizon. Nevertheless, it is important to realize what such reports can and cannot do. On the one hand, these reports encounter substantial and real obstacles

considered. Philadelphia, Pa: Lippincott; 1966. 12. Millis JS. The Graduate Education of Physicians. Chicago, Ill: American Medical Association; 1966.

13. Carnegie Commission on Higher Education. Higher Education and the Nation's Health: Policies for Medical and Dental Education. New York, NY: McGraw-Hill; 1970.

14. Graham R, Royer J, eds. A Handbook for Change. Philadelphia, Pa: WM Fell Co; 1972.

15. American Medical Association Council on Medical Education. Future Directions for Medical Education. Chicago, Ill: American Medical Association; 1982.

16. Friedman CP, Purcell EF. The New Biology and Medical Education: Merging the Biological, Information, and Cognitive Sciences. New York, NY: Josiah Macy Foundation; 1983.

17. Project Panel on the General Professional Education of the Physician. Physicians for the TwentyFirst Century. Washington, DC: Association of American Medical Colleges; 1984.

18. Gastel B, Rogers DE, Clinical Education and the Doctor of Tomorrow. New York, NY: Josiah Macy Foundation; 1989.

19. Shugars DA, O'Neil EH, Bader JD, eds. Healthy America: Practitioners for 2005: An Agenda for Action for U.S. Health Professional Schools. Durham, NC: Pew Health Professions Commission; 1991.

20. Council on Graduate Medical Education. Improving Access to Health Care Through Physician Workforce Reform. Washington, DC: US Dept of Health and Human Services; 1992.

21. Marston RQ, Jones RM, eds. Medical Education in Transition. Princeton, NJ: The Robert to reform, and it is well to ask whether exhortations of official bodies are capable of radically changing the behavior of complex and long-standing academic institutions. But, as we have seen, these reports still fulfill important purposes.

The analysis presented herein should be useful to medical educators as they continue to advocate or implement reform and as they struggle to articulate the role of medical education in our society. This analysis should clarify the agenda of past reform proposals, elucidate the range of previous proposed reforms and the values motivating them, serve as a departure point for future reform efforts, and encourage a healthy skepticism about the potential for change in response to reform proposals. It should also underscore the elements absent from prior reports-such as attention to medical students themselves and a critical examination of the larger social and economic forces impinging on medical education-elements that might benefit from attention in the future.

This work was supported by a Peter W. Swazey Fellowship from the Acadia Institute, Bar Harbor, $\mathrm{Me}$, by a National Research Service Award Fellowship from the Agency for Health Care Policy and Research, and by the Department of Medicine, University of Chicago, and was conducted under the auspices of the Acadia Institute/Medical College of Pennsylvania Project on Undergraduate Medical Education.

I am grateful to Renee C. Fox, PhD, for her considerable help with this work.

Wood Johnson Foundation; 1992.

22. Association of American Medical Colleges. $E d u$ cating Medical Students: Assessing Change in Medical Education, the Road to Implementation. Washington, DC: Association of American Medical Colleges; 1992.

23. O'Neil EH. Health Professions Education for the Future: Schools in Service to the Nation. San Francisco, Calif: Pew Health Professions Commission; 1993.

24. Ashford M. Trends in Medical Education. New York, NY: The Commonwealth Fund; 1949.

25. Levit EJ. Evaluation in the Continuum of Medical Education. Philadelphia, Pa: National Board of Medical Examiners; 1973.

26. Institute of Medicine. Medical Education and Societal Needs: A Planning Report for the Health Professions. Washington, DC: National Academy Press; 1983.

27. Harris DL. Reform in Medical Education and Medical Education in the Ambulatory Setting. Washington, DC: US Dept of Health and Human Services; 1991

28. White KL, Connelly JE, eds. The Medical School's Mission and the Population's Health. New York, NY: Springer-Verlag; 1992.

29. Christakis NA. Implicit Purposes of Proposals to Reform American Medical Education. Philadelphia: Medical College of Pennsylvania; 1995.

30. Cantor JC, Cohen AB, Barker DC, Shuster AL, Reynolds RC. Medical educators' views on medical education reform. JAMA. 1991;265:1002-1006.

31. Freidson E. Profession of Medicine: A Study of the Sociology of Applied Knowledge. Chicago, Ill: University of Chicago Press; 1988. 